\title{
PENGEMBANGAN INTERNET OF THINGS YANG DIMANFAATKAN DALAM MONITORING RUANG SERVER
}

\author{
Agni Isador Harsapranata \\ Universitas Bina Sarana Informatika \\ JL. Kamal Raya No.18, Ringroad Barat, Cengkareng, Jakarta Barat \\ Email : agni.aih@bsi.ac.id
}

\begin{abstract}
Abstrak - Perkembangan teknologi internet saat ini sudah sedemikian maju, teknologi ini sudah dipergunakan diberbagai sektor kehidupan. Oleh karena itu penulis tertarik dalam menggunakan teknologi ini, yaitu Internet Of Things untuk melakukan monitoring ruang server. Perangkat yang dipergunakan oleh penulis menggunakan NodeMCU Lua IoT WIFI CP2102 ESP8266, sensor suhu dan kelembapan DHT11, dan komunikasi data menggunakan internet. Aplikasi yang dipergunakan penulis dalam melakukan monitoring adalah Telegram. Komunikasi Internet Of Things yang penulis pergunakan menggunakan Internet, dan aplikasi Telegram yang dapat di jalankan menggunakan smartphone, sehingga monitoring ruang server dapat dilakukan secara realtime. Selain melaukan monitoring, perangkat tersebut dapat mengirimkan peringatan apabila kondisi suhu dan kelembapan ruang server diluar toleransi yang sudah di tetapkan oleh seorang administrator server.
\end{abstract}

Kata kunci: Internet of Things, Telegram, Arduino.

\section{Pendahuluan}

Dengan adanya teknologi jaringan komputer yang memiliki cakupan global, atau yang sering disebut dengan Internet, mendorong dalam penelitian Internet of Things. Dengan Internet of Things memudahkan dan memungkinkan pengguna dalam melakukan pengiriman dan penerimaan data dari suatu perangkat yang letaknya berada jauh dari jangkau pengguna, dengan syarat perangkat tersebut sudah terkoneksi dengan jaringan Internet. Dalam penelitian ini penulis terdorong untuk melakukan penelitian di bidang tersebut, yang mana kegunaan penelitian ini dapat membantu penulis dalam melakukan monitoring perangkat dari mana saja, selama ada koneksi Internet yang menghubungkannya. Internet of Things yang penulis teliti dipergunakan dalam monitoring suhu ruang server. Karena suhu untuk ruang server sangat berpengaruh terhadap kondisi operasional Server. Apabila suhu berada diatas toleransi dari standart yang ditentukan berakibat akan terjadinya kerusakan server itu sendiri. Dengan server yang tidak beroperasi, mengakibatkan sistem informasi yang berada di dalamnya tidak akan bisa dipergunakan, dan akan mengakibatkan kerugian dalam sisi bisnis suatu perusahaan.

\section{$2 \quad$ Landasan Teori}

Internet.

Internet merupakan sistem komunikasi global jaringan komputer, dimana setiap perangkat saling berhubungan menggunakan standard komunikasi paket protokol
diInternet yaitu TCP / IP, TCP/IP inilah protokol yang menghubungkan semua perangkat yang terdapat di seluruh penjuru dunia. Internet merupakan gabungan dari banyak jaringan yang terdiri dari jaringan milik pribadi atau local area, jaringan umum, jaringan yang dimiliki oleh akademik, jaringan yang dipergunakan untuk bisnis, dan jaringan yang dipergunakan oleh pihak pemerintah yang kesemuanya terhubung ke jaringan ruang lingkup secara global, dalam komunikasi ini perangkat dihubungkan menggunakan berbagai macam teknologi jaringan elektronik, jaringan nirkabel, dan jaringan yang menggunakan media optik. Jaringan global atau jaringan Internet, memuat berbagai macam sumber daya dan juga layanan yang memberikan informasi, contohnya adalah, dokumen yang ditampilkan menggunakan tanda hiperteks yang saling terhubung dan penggunaan aplikasi browser untuk menampilkan World Wide Web $(W W W)$, email atau surat elektronik, komunikasi Voice, dan layanan dalam bertukar file.

Teknologi Internet tidak dimiliki atau dimonopoli secara terpusat tunggal dalam implementasi teknologi, kebijakan atau aturan penggunaannya untuk melakukan akses dikelola oleh pengguna ataupun oleh pemerintah di masing masing negara. Definisi range alamat Protokol Internet (alamat IP) dan Domain Name System (DNS), dikelola oleh organisasi pengelola, untuk lokasi di Indonesia dikelola oleh PANDI (Perkumpulan Pengelola Nama domain Internet Indonesia) sedangkan secara internasional dikelola oleh ICANN (Internet Corporation for Assigned Names and Numbers). 


\section{Internet of Things.}

Internet of Things (IoT) merupakan sistem mesin atau perangkat komputer yang bisa terhubung antara mesin mekanik dan mesin digital, suatu benda, binatang, dan orang yang diberi identitas yang unik (UID) dan kemampuan mesin tersebut untuk melakukan transfer data melalui media jaringan komputer dengan tidak memerlukan bantuan atau interaksi langsung antara manusia ke manusia atau manusia ke komputer. Definisi dari Internet of Things telah berevolusi karena perkembangan beberapa teknologi, komunikasi data secara real-time, Machine Learning, perkembangan sensor, dan sistem yang sudah terpasang didalam perangkat atau sering disebut dengan Embedded System.

Bidang tradisional Embedded System, jaringan sensor nirkabel, control system, otomatisasi termasuk didalamnya adalah otomatisasi yang dimanfaatkan di dalam melakukan kendali suatu rumah atau suatu bangunan, dan yang lainnya, semuanya memberi kontribusi terhadap perkembangan pesat IoT atau Internet of Things.

\section{Arduino.}

Arduino merupakan perusahaan perangkat keras dan perangkat lunak yang menggunakan aplikasi open source, komunitas dari proyek dan pengguna yang melalukan perancangan, melakukan pengembangan menggunakan perangkat mikrokontroler dan kit mikrokontroler perangkat tunggal untuk membangun perangkat digital. Produkproduknya dilisensikan di bawah GNU Lesser General Public License (LGPL) atau GNU General Public License (GPL), yang mengizinkan setiap pengembangan, perubahan, pembuatan papan Arduino dan distribusi perangkat lunak oleh siapa pun. Papan Arduino tersedia secara komersial dalam bentuk preassembled (belum di rakit) atau sebagai kit do-it-yourself (DIY).

Desain perangkat dari sistem Arduino mempergunakan berbagai macam mikroprosesor dan pengontrol. Sistem diperlengkapi dengan port pin yang dipergunakan untuk input / dan port pin yang dipergunakan untuk output $(I / O)$ baik secara digital dan analog yang bisa dihubungkan ke berbagai sistem ekspansi sirkuit dengan fungsi lainnya. Sistem board tersebut memiliki antarmuka komunikasi antara lain serial, termasuk didalamnnya terdapat Universal Serial Bus (USB) pada berbagai model, yang dapat juga dimanfaatkan dalam memasukkan program komputer yang sudah di konfigurasi sesuai dengan kebutuhan pengguna ke dalam memori mikrokontroler. Mikrokontroler dapat diprogram memanfaatkan bahasa pemrograman $\mathrm{C}$ ataupun menggunakan $\mathrm{C}++$. Selain menggunakan aplikasi kompiler tradisional, proyek Arduino menyediakan sistem pengembangan terintegrasi (IDE).

Proyek pertama Arduino dimulai pada tahun 2005 sebagai pelatihan program yang diperuntukan bagi siswa di Interaction Design Institute Ivrea Italia, yang bertujuan untuk menyediakan cara yang murah dan mudah untuk dipahami bagi pemula dan profesional dalam membuat perangkat atau sistem, dimana dapat berinteraksi dengan lingkungan mereka menggunakan sensor dan tindakan dari sensor tersebut. Contoh umum dari perangkat Iot tersebut yang ditujukan untuk penggemar pemula antara lain adalah robot sederhana, sensor termostat, dan detektor dari suatu gerakan.

Nama Arduino didapati berasal dari sebuah bar di Ivrea, Italia, merupakan tempat dari beberapa orang pendiri proyek itu biasa bertemu dan membahas mengenai pengembangannya.

Dalam penggunaan perangkat di penelitian ini penulis menggunakan ESP8266, seperti terlihat di gambar 1. Dan untuk skema perangkat tersebut dapat dilihat di gambar 2.

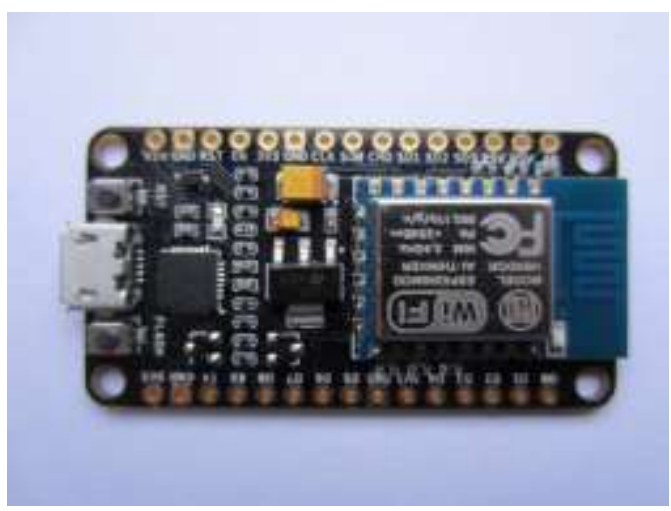

Gambar 1. ESP 8266

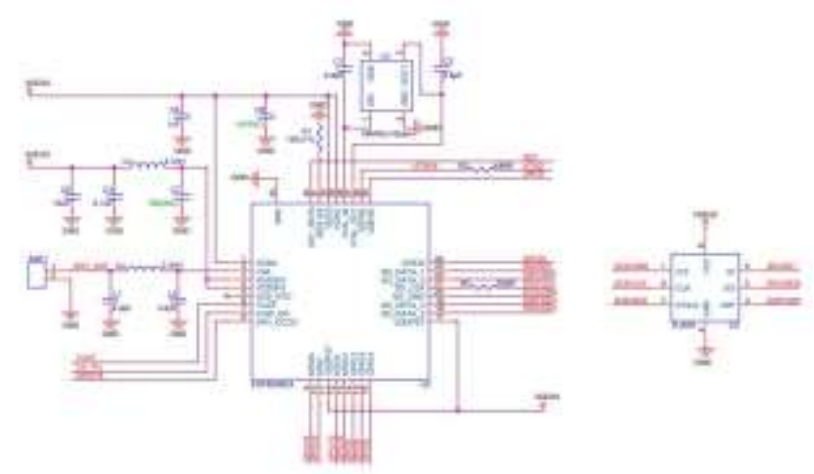

Gambar 2. Skema ESP 8266.

\section{DHT11.}

Perangkat Sensor yang dipergunakan untuk mengukur suhu dan kelembapan secara digital, dimana penulis menggunakan DHT11 merupakan sensor yang didalamnya dapat memberikan respon keluaran sinyal digital dalam memberikan informasi suhu maupun kelembaban. Teknologi yang diterapkan ke dalam modul digital dan teknologi dalam melakukan penginderaan suhu dan kelembaban diterapkan untuk memastikan kalau produk sensor ini memberikan hasil yang presisi dan dalam penggunaanya stabil apabila dipergunakan dalam jangka waktu panjang. 
Sensor ini mencakup komponen resistif basah yang dipergunakan dalam mengukur kelembapan dan perangkat yang dipergunakan untuk mengukur suhu yaitu NTC (Negative Temperature Coefficient), dan terhubung dengan mikrokontroler 8-bit berkinerja sangat presisi. Diagram skematik Modul Sensor Humiture seperti terlihat di gambar 3.

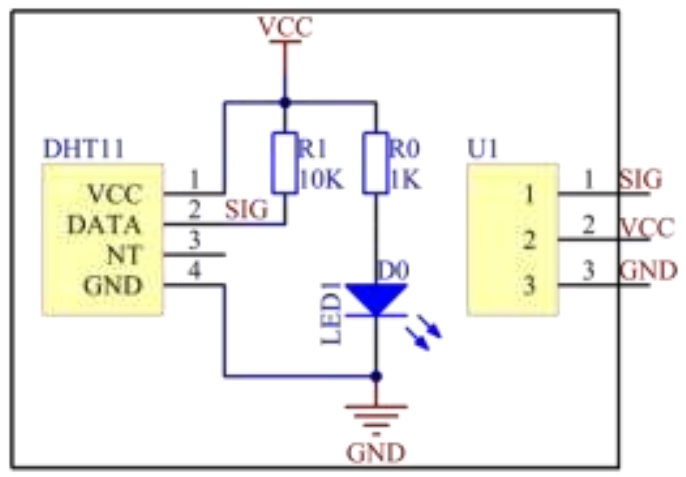

Gambar 3. Diagram DHT 11.

Terdapat tiga pin seperti terlihat di gambar 4 yang tersedia untuk digunakan, yaitu : VCC, GND, dan DATA. Proses komunikasi dari lingkungan ke sistem pembaca adalah dimulai dengan jalur DATA yang mengirimkan sinyal awal ke DHT11, dan DHT11 menerima sinyal dan mengembalikan sinyal jawaban yang berisi informasi mengenai data Suhu dan Kelembapan. Kemudian host sistem menerima sinyal jawaban dan mulai menerima data humiture 40 bit, 40 bit tersebut terdiri dari integer kelembaban 8 bit, desimal kelembaban 8-bit, integer suhu 8-bit, desimal suhu 8-bit, dan checksum 8-bit.

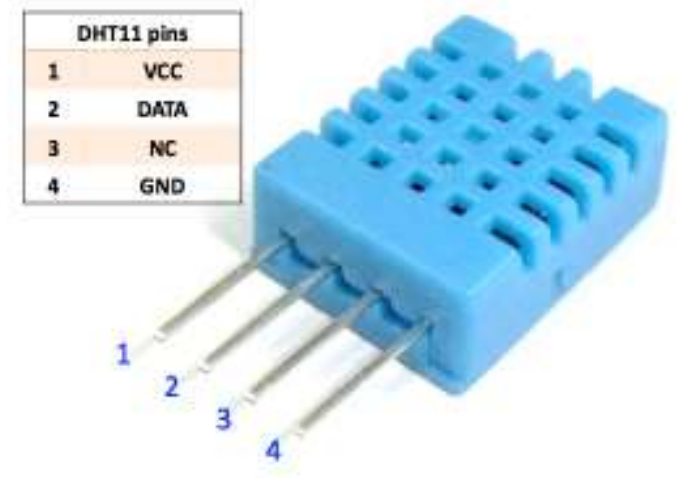

Gambar 4. DHT 11.

\section{Telegram.}

Telegram merupakan aplikasi pengiriman pesan secara instan berbasis cloud dan layanan voice over Internet protocol. Aplikasi Telegram yang berada disisi pengguna dapat dipasang diatas sistem operasi Android, iOS, Windows Phone, macOS dan juga Linux. Pengguna aplikasi tersebut dapat mengirim pesan dan dapat saling bertukar foto, video, stiker, audio, dan file jenis apa pun.

Aplikasi Telegram yang dipasang disisi pengguna merupakan perangkat lunak open source akan tetapi kode sumber untuk versi terbaru tidak serta merta dengan cepat diumumkan ke pengguna secara luas, sedangkan aplikasi kode sisi servernya adalah close source. Layanan telegram ini juga menyediakan API yang dipergunakan untuk pengembang independen. Pada bulan Maret 2018, Telegram mengumumkan bahwa aplikasi tersebut dimiliki oleh 200 juta pengguna aktif bulanan.

Komunikasi Pesan dan media menggunakan Telegram dienkripsi saat disimpan di servernya, dan komunikasi klien-server juga dienkripsi. Layanan ini menyediakan enkripsi ujung ke ujung untuk panggilan suara, dan obrolan terenkripsi dari sisi ujung ke ujung yang lain secara opsional antara dua pengguna online, namun tidak untuk komunikasi secara group.
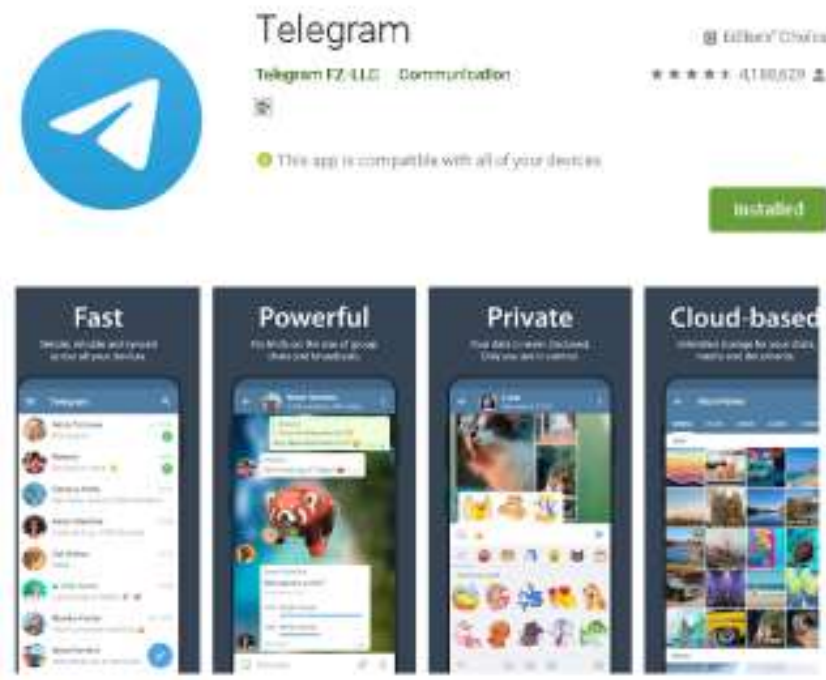

Gambar 5. Telegram di dalam Android.

\section{Perancangan Sistem}

Perancangan sistem yang penulis lakukan mempergunakan teori dari model SDLC ( System Development Life Cycle) yang salah satunya adalah waterfall, dimana dalam model ini tahapan yang dilakukan adalah Requirements Analysis , Design, Implementation, Verification, Maintenance, seperti dapat dilihat di gambar 5 .

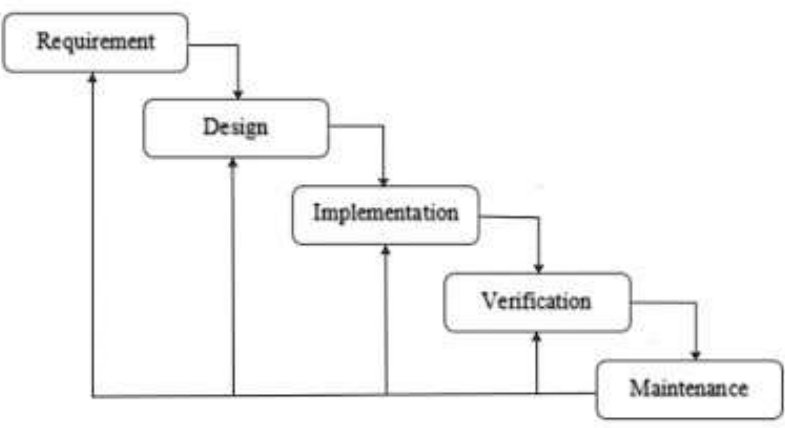

Gambar 5. Model Waterfall. 


\section{Requirement.}

Pada tahap ini penulis menganalisa permasalah yang terjadi melalui observasi di ruang server, mengenai kendala yang dihadapi untuk monitoring suhu dan kelembapan.

\section{Design.}

Pada tahap ini, penulis melakukan perencanaan sistem susuai dengan kebutuhan sistem yang akan di bangun, membuat skema tahapan tahapan sistem berjalan menggunakan diagram blok sehingga memudahkan di dalam pembacaan tahapan tahapan sistem berjalan.

\section{Implementation.}

Pada tahapan ini penulis menuangkan skema diagram kedalam bentuk kode program, yang nantinya akan di masukkan ke dalam memori arduino, dimana penulis menggunakan arduino ESP 8266. Selain menggunakan arduino penulis menggunakan DHT 11 sebagai pembaca atau sensor suhu dan kelembapan, yang nantinya akan diletakkan di ruang server. Dari arduino, menggunakan signal wifi, data akan di transmisikan menggunakan Internet ke cloud Telegram. Kendali sensor dapat menerima dan mengirim data menggunakan Aplikasi Telegram yang berada di tangan seorang administrator ruang server.

\section{Verification.}

Pada tahap ini penulis melakukan uji coba sistem yang sudah di implementasi, dimana dalam pengujian ini penulis melakukan pengujian fungsionalitas setiap perangkat, sehingga seluruh kode program dapat memberikan hasil yang benar $100 \%$.

\section{Maintenance.}

Pada tahap akhir ini, penulis melakukan pemeliharaan, pemeliharaan yang dilakukan termasuk juga dengan perbaikan dari kesalahan yang tidak ditemukan di tahap verification.

\section{Implementasi dan Pengujian}

Dalam penggunaan IOT ini seorang Administrator Ruang Server dapat memantau Ruang Server dengan memberi perintah "SUHU" melalui aplikasi Telegram (Aplikasi yang berjalan diatas sistem operasi Android", dan kemudian sistem monitoring akan memberi informasi melalui internet, dan diterima oleh telegram, seperti terlihat di gambar 6.

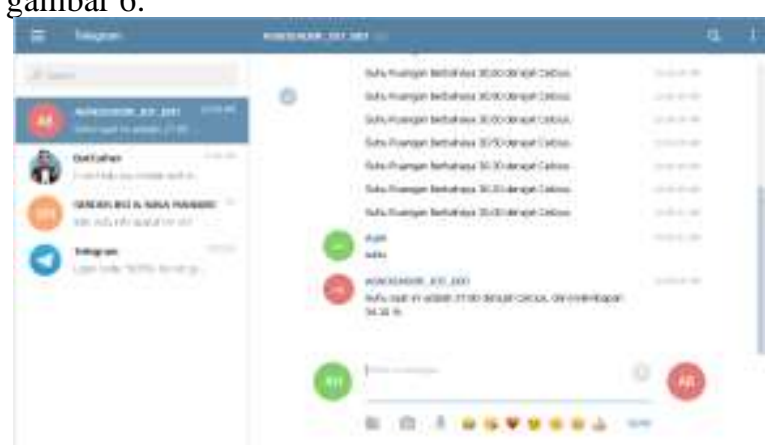

Gambar 6. Hasil Perintah Suhu.
Kemudian ada triger yang akan memberi peringatan apabila suhu Ruang Server diatas normal, disini adalah diatas sama dengan 30 derajat Celcius, Informasi ini akan dikirim secara terus menerus ke Telegram Administrator Ruang Server, sampai diambil tindakan yang membuat suhu ruangan dibawah 30 Derajat Celcius. Seperti terlihat di gambar 7.

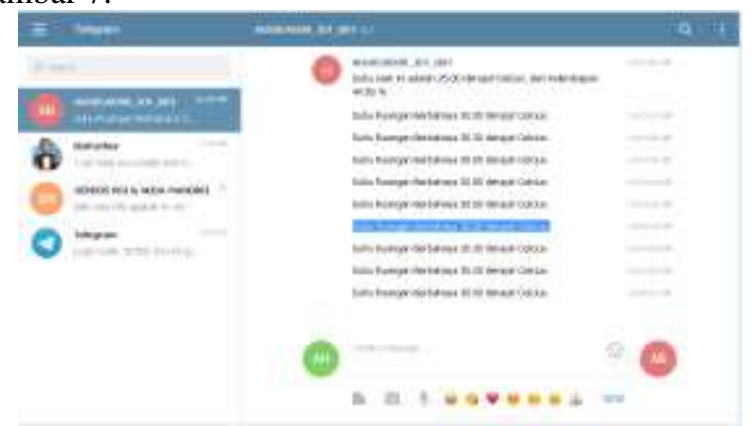

Gambar 7. Peringatan Ruang Server Berbahaya.

Dan berikut penulis sertakan alur program menggunakan Flowchart, seperti terlihat di gambar 8.

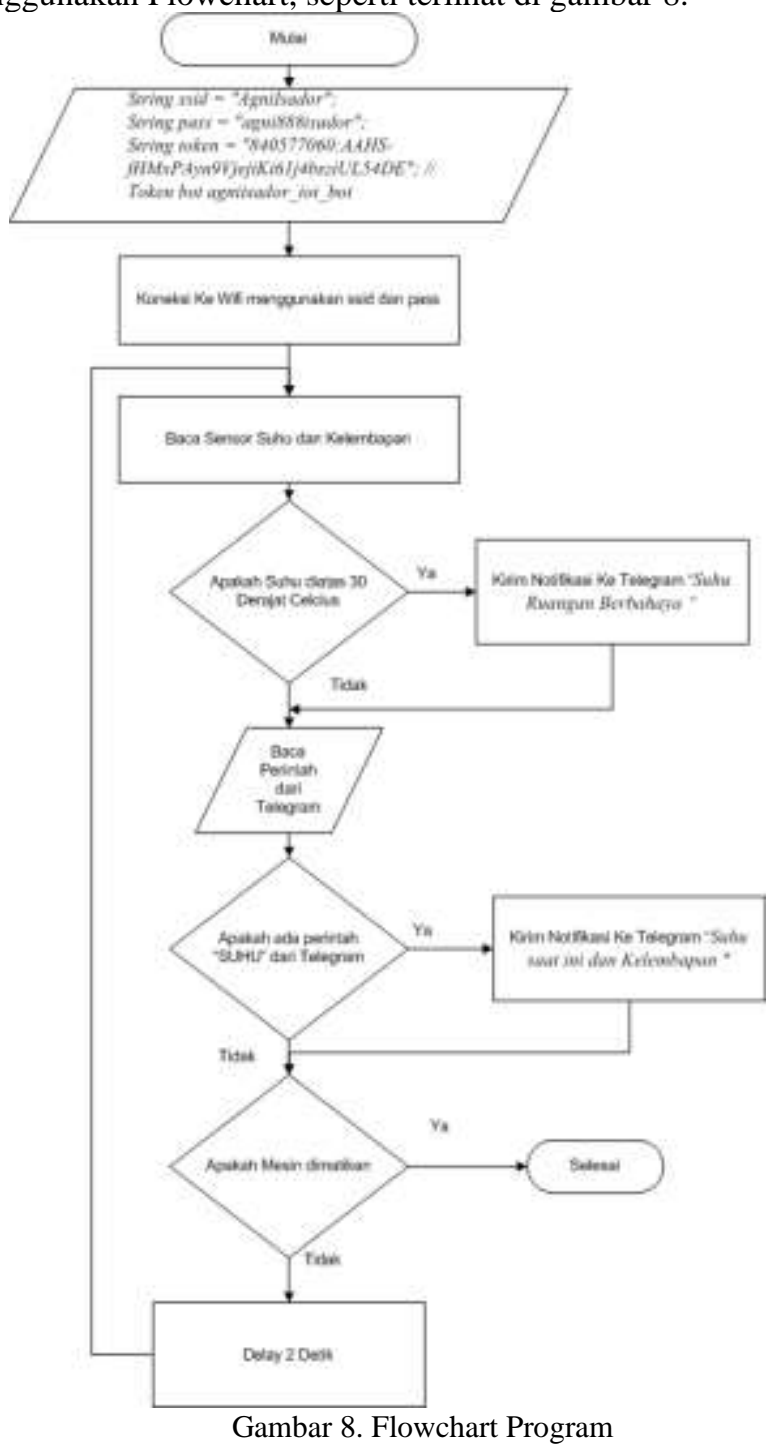


Dan berikut penulis sertakan kode program yang dipergunakan didalam arduino:

\section{//Aplikasi dibuat oleh Agni Isador Harsapranata}

\#include "DHT.h" //Memasukkan prosedur aplikasi DHT

\#include "CTBot.h" I/Memasukkan prosedur aplikasi Bot

\#include <ESP8266WiFi.h> // menggunakan insialisasi porgram ESP8266WiFi

\#define DHTTYPE DHT22 // menggunakan inisialisasi program DHT 22

String ssid = "AgniIsador"; //Memasukkan SSID Wifi

String pass = "agni888isador"; //Memasukkan password Wifi

String token $=$ "840577060:AAHS -

fHMxPAyn9VjejiKi61j4bsziUL54DE"; I/Token bot

agniisador_iot_bot Telegram

CTBot myBot;

// Inisialisasi DHT Sensor

uint8_t DHTPin $=$ D8; //Port Digital 8 sebagai pembaca sensor

Suhu dan Kelembapan

uint8_tled $=2$;

DHT dht(DHTPin, DHTTYPE);

float SuhuRuangServer; //Menetapkan variable SuhuRuangServer float KelembapanRuangServer; I/Menetapkan variabel KelembapanRuangServer

\section{void setup() \{}

// Melakukan inisialisasi port serial untuk komunikasi data Serial.begin(115200); //Inisialisasi kecepatan transfer serial delay(100); //Tunggu 0.1 detik

pinMode(DHTPin, INPUT);

dht.begin();

myBot.wifiConnect(ssid, pass); //Melakukan koneksi Internet menggunakan Wifi dengan SSID dan password yang sudah di tetapkan

myBot.setTelegramToken(token); //Inisialisasi Token untuk Telegram yang sudah dibuat, dimana token ini sebagai identitas perangkat untuk mengirim dan menerima perintah dari Telegram pinMode(led, OUTPUT);

digitalWrite(led, HIGH); // Mematikan lampu mesin(Fungsi inverted logic!)

\}

void $\operatorname{loop}()\{$

TBMessage msg;

SuhuRuangServer = dht.readTemperature(); // Mengambil Nilai sensor SuhuRuangServer

KelembapanRuangServer $=$ dht.readHumidity(); // Mengambil

Nilai sensor KelembapanRuangServer

String suhu=String(SuhuRuangServer,2);

String kelembapan=String(KelembapanRuangServer,2);

if (isnan(SuhuRuangServer) || isnan(SuhuRuangServer))

i

//Serial.println("Gagal membaca dari sensor DHT"); \}

else l

if (SuhuRuangServer $>=30.00)$ 亿

myBot.sendMessage(msg.sender.id, "Suhu Ruangan Berbahaya " + suhu + (String)" derajat Celcius."); // Memberi informasi ke Administrator

\}

\}

if (myBot.getNewMessage(msg)) //Mengambil Perintah dari Aplikasi Telegram

I

if (msg.text.equalsIgnoreCase("SUHU")) \{

myBot.sendMessage(msg.sender.id, "Suhu saat ini adalah" + suhu + (String)" derajat Celcius, dan Kelembapan " + kelembapan + (String)" \%" ); // Memberi informasi ke Administrator

\} // Memberi informasi suhu dan kelembapan apabila mesin menerima perintah dari Telegram

else \{

// Melakukan pengiriman informasi ke telegram mengenai penggunaan perintah untuk menggunakannya

String reply;

reply $=($ String $) "$ Welcome $"+$ msg.sender.username +

(String)" Untuk Mengetahui Suhu dan kelembapan ruangan ketik SUHU, apabila suhu diatas 30 derajat Celcius, akan ada peringatan lewat telegram ";

myBot.sendMessage(msg.sender.id, reply); \}

\}

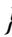

delay(2000); //Tunggu Selama 2 Detik

\section{Simpulan}

Dari hasil pembahasan yang penulis lakukan berjudul " PENGEMBANGAN INTERNET OF THINGS YANG DIMANFAATKAN DALAM MONITORING RUANG SERVER" tersebut dapat ditarik ikthisar bahwa, dengan menggunakan IoT atau internet of things pada pengembangan sistem monitoring ruang server dapat menghasilkan perangkat yang dapat membantu aktifitas administrator dalam melakukan monitoring ruang server.

\section{Kepustakaan}

Jogiyanto, H. (2005). Analisis \& Desain Sistem Informasi: Pendekatan Terstruktur, Teori, dan Aplikasi Bisnis. Yogyakarta: Andi.

[2] Wikipedia. (2016, February 2). ESP8266. Retrieved from ESP8266:

https://www.esp8266.com/wiki/doku.php?id=nodemcu

[3] Wikipedia. (2017, April 5). Humiture Sensor Module. Retrieved from Humiture Sensor Module: http://wiki.sunfounder.cc/index.php?title=Humiture_Sensor_M odule

[5] Wikipedia. (2019, September 24). Arduino. Retrieved from Arduino: https://en.wikipedia.org/wiki/Arduino

[6] Wikipedia. (2019, October 12). Internet. Retrieved from Internet: https://en.wikipedia.org/wiki/Internet

[7] Wikipedia. (2019, October 14). Internet of Things. Retrieved from Internet of Things:

https://en.wikipedia.org/wiki/Internet_of_things 